\title{
Effect of the environment and diet on the physiological variables of sheep in the Brazilian semi-arid region
}

\section{Efeito do ambiente e dieta sobre as variáveis fisiológicas de ovinos no semiárido brasileiro}

\author{
Nayanne Lopes Batista Dantas ${ }^{1 *}$; Bonifácio Benicio de Souza ${ }^{2}$; Maycon Rodrigues \\ da Silva3; Gustavo de Assis Silva4; João Paulo da Silva Pires ${ }^{5}$; Luanna Figueirêdo \\ Batista $^{3}$; Mateus Freitas de Souza ${ }^{5}$; Dermeval Araújo Furtado ${ }^{6}$
}

\begin{abstract}
This study aimed to evaluate and compare the physiological variables of three sheep genotypes: Morada Nova, Somalis, and Dorper x Somalis crossbreed regarding the environment and diet in the Brazilian semi-arid region by using 30 animals (10 from each genetic group). Five of these animals had $30 \%$ of the tifton hay replaced by hairy woodrose hay. The temperature and relative air humidity were registered, the black globe temperature and humidity index (BGHI) was calculated, and the rectal temperature (RT), respiratory rate (RR), heart rate (HR), and surface temperature (ST) were measured in the morning and afternoon. The experimental design was a completely randomized design in a $3 \times 2 \times$ 2 factorial scheme, which consisted of three genotypes, two diets, and two periods, and five replications each. BGHI presented values of 81 in the shade and 90 in the sun and a significant difference $(\mathrm{P}<0.05)$ was observed for the studied variables in relation to the periods, with higher values in the afternoon. The average ST was $35.48{ }^{\circ} \mathrm{C}$ in the morning and $38.11{ }^{\circ} \mathrm{C}$ in the afternoon. Morada Nova presented the lowest RT and RR $(\mathrm{P}<0.05)$ among the genetic groups, with a higher tolerance to heat. The $30 \%$ substitution of tifton hay by hairy woodrose hay did not negatively affect the thermoregulatory capacity of sheep. The studied genetic groups were adapted and tolerant to climate conditions of the Brazilian semi-arid region.
\end{abstract}

Key words: Adaptability. Animal welfare. Hairy woodrose. Sheep farming.

\section{Resumo}

Objetivou-se com este trabalho, avaliar e comparar as variáveis fisiológicas de três grupos genéticos de ovinos: Morada Nova, Somalis e mestiços de Dorper x Somalis com relação ao ambiente e à dieta no semiárido brasileiro, utilizando-se 30 animais, 10 de cada grupo genético, sendo que cinco tiveram $30 \%$ do feno de tífton substituído por feno de jitirana. Foi coletada a temperatura e umidade relativa

1 Dr em Medicina Veterinária, Universidade Federal de Campina Grande, UFCG, Centro de Saúde e Tecnologia Rural, Patos, PB, Brasil.E-mail: nayanne.lb@gmail.com

2 Prof. Titular, UFCG, Centro de Saúde e Tecnologia Rural, Patos, PB, Brasil. E-mail: bonif@cstr.ufcg.edu.br

3 Discentes do Curso de Doutorado do Programa de Pós-Graduação em Medicina Veterinária, UFCG, Centro de Saúde e Tecnologia Rural, Patos, PB, Brasil. E-mail: mayconrvet@gmail.com; luanna 151@hotmail.com

4 Dr. em Medicina Veterinária, Extensionista Rural, Instituto Agronômico de Pernambuco, IPA, Itapetim, PE, Brasil. E-mail: gustavo.assis@ipa.br

5 Graduados em Medicina Veterinária, UFCG, Centro de Saúde e Tecnologia Rural, Patos, PB, Brasil. E-mail: joaopaulopires777@, gmail.com; freitasmateus22@gmail.com

6 Prof. Titular, UFCG, Centro de Tecnologia e Recursos Naturais, Campina Grande, PB, Brasil. E-mail: araujodermeval@gmail.com

* Author for correspondence 
do ar, calculado o ITGU e aferidas a temperatura retal (TR), frequência respiratória (FR) e cardíaca (FC) e temperatura superficial (TS), nos turnos manhã e tarde. Utilizou-se o delineamento inteiramente casualizado (DIC), e o esquema fatorial $3 \times 2 \times 2$, sendo três grupos genéticos, duas dietas e dois turnos, com cinco repetições cada. Os valores para ITGU foram de 81 na sombra e 90 no sol e houve diferença $(\mathrm{P}<0,05)$ para as variáveis estudadas com relação aos turnos, sendo mais elevados à tarde. A TS média dos ovinos foi de 35,48 pela manhã e $38,11^{\circ} \mathrm{C}$ à tarde, e Morada Nova apresentou TR e FR menor (P $<0,05)$ entre os grupos genéticos e demonstraram maior tolerância ao calor. A substituição de $30 \%$ de feno de tífton por feno de Jitirana, não repercutiu negativamente na capacidade termorregulatória dos ovinos. Os grupos genéticos estudados apresentaram-se adaptados e tolerantes às condições climáticas do semiárido brasileiro.

Palavras-chave: Adaptabilidade. Bem-estar animal. Jitirana. Ovinocultura.

\section{Introduction}

Sheep production is very significant in Brazil, especially in the Northeast region, which holds $63 \%$ of the herd, with more than 11 million head (IBGE, 2016). Climate is a determining factor for the success of this productive activity and the interaction animal $\times$ climate should be considered in order to improve the efficiency of livestock exploitation since the animals present different responses to the peculiarities of the climate of each region (LEITÃO et al., 2013).

The Morada Nova sheep are descended from Iberian and African sheep and originated in the Northeast of Brazil, being adjusted to the regional environmental conditions (FACÓ et al., 2008). Sheep of this breed have an aptitude for meat and skin and are highly appreciated in the international market. It is a rustic breed adapted to climate adversities.

The Brazilian Somalis breed is not a native breed but received this name because it was introduced in the country severalyears ago (in 1939), crossbreeding with local animals (RIBEIRO; GARCIA, 2016). They have white pelage, with black head and neck, and ability to produce meat and skin. They are rustic animals, adapting well to the climate conditions of the semi-arid region (ARCO, 2018).

According to Barbosa Neto et al. (2010), one of the alternatives to increase Brazilian production through animal genetic improvement would be to harness the potential of different breeds, using crossbreeding selection strategies. The Dorper breed can be used for this purpose because it was created to produce meat as efficiently as possible under varied and even unfavorable environmental conditions, being able to resist and maintain a good health and body condition (ARCO, 2018).

To estimate animal heat tolerance, rectal temperature and respiratory rate are the best physiological variables (OLIVEIRA et al., 2013). However, the assessment of adaptability can be complemented with variables such as heart rate and surface temperature.

Cruz Júnior et al. (2015) and Paim et al. (2013) observed that thermographic evaluation surveys in sheep can adequately evaluate temperature gradients and identify breeds that are more or less heat tolerant. Seixas et al. (2017) observed a high correlation between environmental indices and the surface temperature of sheep, demonstrating the importance of establishing values indicative of thermal discomfort to adopt measures to mitigate thermal stress and not compromise the productive performance of the breeds.

In addition to the importance of the development of researches related to the adaptability of different breeds to the Brazilian semi-arid region, there is a need for studies on the use of viable native forages that can be used in animal feed, thus complementing studies that aim to promote the sustainability of sheep farming in this region.

Arruda et al. (2010) pointed out that food evaluation research allows us to envisage perspectives of supplementation or partial 
substitution of ingredients to meet the nutritional requirements of the animal without compromising productive, reproductive, or health performance.

The Caatinga vegetation presents a great diversity in its flora, with numerous shrub, arboreal, and herbaceous species consumed by ruminants. In the herbaceous stratum, species such as the hairy woodrose, belonging to the Convolvulaceae family, constitute a promising alternative of roughage conservation via hay (LEÃO et al., 2017), presenting a good acceptability by sheep (SILVA et al., 2017).

The aim of this study was to evaluate and compare the physiological variables (rectal temperature, respiratory rate, heart rate, and surface temperature) of three genetic groups of sheep (Morada Nova, Somalis, and Dorper $\mathrm{x}$ Somalis crossbreed) in order to verify genetic differences regarding their adaptation to the Brazilian semi-arid in relation to the periods and diet offered.

\section{Material and Methods}

The experiment was carried out from November 2015 to January of 2016 at the Nucleus of Research for the Semiarid Development (NUPEÁRIDO), in the experimental farm of the Federal University of Campina Grande (UFCG), located in Patos, Paraíba, in Brazilian semi-arid region, with geographical coordinates of $07^{\circ} 05^{\prime} 28^{\prime \prime} \mathrm{S}$ and $37^{\circ} 16^{\prime} 48^{\prime \prime \prime} \mathrm{W}$, and $250 \mathrm{~m}$ of altitude. According to Köppen, the regional climate is classified as $\mathrm{BSH}$, with average annual maximum and minimum temperatures of 32.9 and $20.8{ }^{\circ} \mathrm{C}$, respectively, and relative air humidity of $61 \%$ (INMET, 2018).

Thirty intact male sheep of the genetic group Morada Nova, Somalis, and Dorper x Somalis crossbreed with approximately 150 days of age and average live weight of $22.5 \pm 2 \mathrm{~kg}$ were used in the experiment, being 10 animals from each genetic group. These animals received a diet composed of tifton (Cynodon sp.) hay and concentrate (ground grain corn and soybean meal) in the 60:40 proportion, mineral supplementation, and water ad libitum.

Half of the animals had the proportion of $30 \%$ of the roughage (tifton hay) replaced by hairy woodrose hay (Merremia aegyptia). Isoproteic and isoenergetic diets were formulated for this category of sheep aiming at a daily average weight gain of 250 grams, according to the National Research Council (NRC, 2007). The bromatological analysis of the feed ingredients was carried out in the Laboratory of Animal Nutrition of the Center for Health and Rural Technology of the Federal University of Campina Grande (Table 1).

These animals were vaccinated and dewormed at the beginning of the experimental period and housed in individual wooden stalls, measuring $0.80 \times 1.20 \mathrm{~m}$ and containing feeding and drinking troughs, during the entire experimental period, which lasted 75 days, with 15 days of adaptation to the environment, diet, and general management, and 60 days of data collection. The animals remained confined in the shed, without access to sunny environments. The study obtained a favorable opinion from the research ethics committee (protocol No. 168-2014).

The black globe temperature and humidity index (BGHI) was calculated in the shade environments, where the animals were, and in the sun environment, outside the shed, aiming at comparing both environments. For this, the formula described by Buffington et al. (1981) was used: BGHI $=$ Tbg $+0.36 \mathrm{Tdp}+41.5$, where Tbg is the black globe temperature and Tdp is the dew point temperature. These temperatures, as well as the temperature and relative air humidity, were recorded through black globe thermometers coupled to a data logger and installed in shade and sun environments. For the morning and afternoon periods, we considered the time of 9 a.m. for weighing leftovers and feeding the animals and 3 p.m. for recording the highest temperature. 
Table 1. Bromatological composition of ingredients of the experimental diets (in \%) based on dry matter (DM).

\begin{tabular}{|c|c|c|c|c|c|c|c|}
\hline \multicolumn{8}{|c|}{ DIET WITH HAIRY WOODROSE } \\
\hline INGREDIENT & $\%$ & $\mathrm{DM}(\%)$ & $\mathrm{CP}(\%)$ & NDF $(\%)$ & TDN (\%) & $\mathrm{Ca}(\%)$ & $\mathrm{P}(\%)$ \\
\hline Grain corn & 20.65 & 17.88 & 1.65 & 1.84 & 16.52 & 0.00 & 0.05 \\
\hline Soybean meal & 16.88 & 15.57 & 8.08 & 2.45 & 14.18 & 0.04 & 0.10 \\
\hline Tifton hay & 42.00 & 39.22 & 3.36 & 34.86 & 21.84 & 0.21 & 0.06 \\
\hline Hairy woodrose hay & 18.00 & 16.83 & 1.65 & 14.04 & 10.08 & 0.02 & 0.03 \\
\hline Limestone & 0.13 & 0.13 & 0.00 & 0.00 & 0.00 & 0.05 & 0.00 \\
\hline Phosphate & 0.11 & 0.11 & 0.00 & 0.00 & 0.00 & 0.02 & 0.02 \\
\hline Salt & 1.00 & 0.97 & 0.00 & 0.00 & 0.00 & 0.14 & 0.07 \\
\hline Bentonite & 1.23 & 1.22 & 0.00 & 0.00 & 0.00 & 0.00 & 0.00 \\
\hline TOTAL & 100 & 91.93 & 14.74 & 53.19 & 62.62 & 0.50 & 0.33 \\
\hline \multicolumn{8}{|c|}{ DIET WITHOUT HAIRY WOODROSE } \\
\hline INGREDIENT & $\%$ & $\mathrm{DM}(\%)$ & $\mathrm{CP}(\%)$ & NDF $(\%)$ & TDN (\%) & $\mathrm{Ca}(\%)$ & $\mathrm{P}(\%)$ \\
\hline Grain corn & 21.48 & 18.59 & 1.72 & 1.91 & 17.18 & 0.00 & 0.05 \\
\hline Soybean meal & 17.44 & 16.09 & 8.34 & 2.53 & 14.65 & 0.04 & 0.10 \\
\hline Tifton hay & 60.00 & 56.03 & 4.81 & 49.8 & 31.20 & 0.29 & 0.08 \\
\hline Limestone & 0.03 & 0.03 & 0.00 & 0.00 & 0.00 & 0.01 & 0.00 \\
\hline Phosphate & 0.05 & 0.05 & 0.00 & 0.00 & 0.00 & 0.01 & 0.01 \\
\hline Salt & 1.00 & 0.97 & 0.00 & 0.00 & 0.00 & 0.14 & 0.07 \\
\hline TOTAL & 100 & 91.76 & 14.87 & 54.24 & 63.03 & 0.49 & 0.31 \\
\hline
\end{tabular}

*DM: dry matter; CP: crude protein; NDF: neutral detergent fiber; TDN: total digestible nutrients; Ca: calcium; P: phosphorus.

Once a week during the experimental period, in the morning and afternoon periods, the physiological variables of all sheep were measured. The respiratory rate (RR) was measured with a flexible stethoscope placed in the thoracic region by counting the number of movements for 15 seconds, which was multiplied by four to obtain the number of movements per minute ( $\mathrm{mov} \mathrm{min}^{-1}$ ). After obtaining RR, the rectal temperature (RT) was measured by a veterinary clinical thermometer inserted in the rectum of the animal for two minutes, being the result expressed in degrees Celsius $\left({ }^{\circ} \mathrm{C}\right)$. The variables were measured in the facilities where the animals remained inside the stalls without the need of containment since they were docile and were already adapted to the management and researchers.

The heart rate (HR) was measured using a flexible stethoscope placed directly on the left thoracic region at the height of the aortic arch and counting the number of movements for 15 seconds, being the obtained value multiplied by four to obtain the number of beats per minute (beats $\mathrm{min}^{-1}$ ).

The surface temperature (ST) was recorded through a Fluke Ti25 infrared thermographic camera. The thermograms were analyzed using the software SmartView 4.2. The temperature was evaluated in five points on the right side of the animal's body, namely forehead, neck, side, belly, and shin, being the average expressed in degrees Celsius $\left({ }^{\circ} \mathrm{C}\right)$ and considering an emissivity of 0.98 .

The experimental design was a completely randomized design in a $3 \times 2 \times 2$ factorial scheme, which consisted of three genotypes, two diets, and two periods of evaluations (repeated plots in time), and five replications each. The data were analyzed through the Sistema de Análises Estatísticas e Genéticas - SAEG (UFV, 1993), with the Tukey's test at $5 \%$ significance level. 


\section{Results and Discussion}

A difference $(\mathrm{P}<0.05)$ was observed for all the studied variables (air temperature, relative air humidity, and BGHI) in relation to the periods, with higher values in the afternoon for air temperature and BGHI in the shade and sun, while RH presented lower values in the afternoon period (Table 2).

Table 2. Means of air temperature, relative air humidity, and black globe temperature and humidity index (BGHI) in the shade and sun in the morning and afternoon periods.

\begin{tabular}{ccccc}
\hline Period & $\mathrm{AT}\left({ }^{\circ} \mathrm{C}\right)$ & $\mathrm{RH}(\%)$ & BGHI SHADE & BGHI SUN \\
\hline Morning & $29.4 \pm 1.8 \mathrm{~B}$ & $58.3 \pm 13.9 \mathrm{~A}$ & $79.3 \pm 1.6 \mathrm{~B}$ & $88.3 \pm 4.3 \mathrm{~B}$ \\
Afternoon & $35.3 \pm 3.3 \mathrm{~A}$ & $38.1 \pm 15.4 \mathrm{~B}$ & $82.7 \pm 3.0 \mathrm{~A}$ & $91.8 \pm 7.5 \mathrm{~A}$ \\
$\mathrm{CV}$ & 8.3 & 30.4 & 2.9 & 6.8 \\
\hline
\end{tabular}

Means followed by different letters in the column are different from each other $(\mathrm{P}<0.05)$ by the Tukey's test.

Air temperature and relative humidity are the two most important environmental variables regarding animal thermal comfort zone because environments with high temperatures present a reduced thermal gradient between the animal surface and the environment, resulting in a lower heat dissipation efficiency in the sensitive form through the radiation, conduction, and convection.

In these cases, animals dissipate heat to the environment through the latent form by skin evaporation (sweating) and mainly by increasing respiratory rate. The increased respiratory movements result in heat loss because the inspired air, upon coming into contact with the respiratory tract, is moistened. At the expiration, the air is saturated with water, which goes from the liquid to the vapor state (respiratory evaporation). This process releases energy, causing the animal to lose about 540 calories to each gram of evaporated water (HEWITT, 2015).

The relative air humidity was higher $(\mathrm{P}<0.05)$ in the morning, presenting an inversely proportional correlation with the temperature, which is due to the temperature variation during the day. A higher potential for evaporation of the water in the air was observed as temperature increased in the afternoon when compared to the morning period, leading to a decrease in humidity.

For wooless adult sheep, the thermal comfort zone (TCZ) is optimum for temperatures between 20 and $30{ }^{\circ} \mathrm{C}$, with a relative humidity between 50 and $80 \%$, being considered as an upper critical temperature (UCT) when it is higher than $34{ }^{\circ} \mathrm{C}$ (BAÊTA; SOUZA, 2010). In this study, in the afternoon period, AT and $\mathrm{RH}\left(35.3{ }^{\circ} \mathrm{C}\right.$ and $38.1 \%$, respectively) were out of the TCZ advocated by the aforementioned authors.

Souza (2010) states that BGHI values around 83 indicate a medium-high stress condition for sheep. The value of BGHI in the shade was 79.3 in the morning and 82.7 in the afternoon period. This increase was due to a higher ambient temperature in the afternoon period. Therefore, even in the shade, the animals were in a medium-high stress condition in the afternoon.

In the sun, BGHI values reached 88.3 and 91.8, in the morning and afternoon periods, respectively, which are characteristic values of a high stress. Although the animals were maintained in an intensive system, without access to the sun environment, there is a retransmission of heat coming from the radiation, which is partially reflected neighboring objects and bodies. This influences the temperature in the facilities, adding heat to the animals through 
the conduction and winds (by convection), interfering with their thermal comfort.

The exposure of sheep to high temperatures, as well as to high BGHI values, causes changes in their organism capable of bypassing the stressor effect of the environment. However, the activation of these thermoregulatory measures, such as an increased RR, requires an energy expenditure of the animal, which can imply productive losses since part of the energy that would be used for growth and production of meat and/or milk will be directed to the maintenance of thermal homeostasis.

No interaction was observed between genetic groups, periods, and diets for RR and HR of sheep (Table 3), but the Morada Nova breed presented a lower RR $(\mathrm{P}<0.05)$ when compared to Dorper $\mathrm{x}$ Somalis crossbreed, not differing from Somalis. No difference was observed for RR in relation to the diets, i.e. the inclusion of hairy woodrose hay did not cause an increase in this variable.

Table 3. Means of respiratory rate and heart rate of Somalis, Dorper x Somalis, and Morada Nova sheep as a function of the genetic groups, periods, and diets.

\begin{tabular}{lcc}
\hline \multicolumn{1}{c}{ Factor } & \multicolumn{2}{c}{ Physiological variables } \\
\hline GENETIC GROUP & RR $\left(\mathrm{mov} \mathrm{min}^{-1}\right)$ & HR $\left(\right.$ beats $\left.\mathrm{min}^{-1}\right)$ \\
\hline Somalis & $72.6 \pm 24.2 \mathrm{AB}$ & $115.7 \pm 12.7 \mathrm{~B}$ \\
\hline Dorper x Somalis & $79.2 \pm 20.4 \mathrm{~A}$ & $121.1 \pm 14.6 \mathrm{~B}$ \\
Morada Nova & $63.5 \pm 22.5 \mathrm{~B}$ & $129.4 \pm 16.1 \mathrm{~A}$ \\
\hline PERIOD & & \\
\hline Morning & $55.2 \pm 9.8 \mathrm{~B}$ & $111.4 \pm 10.0 \mathrm{~B}$ \\
Afternoon & $88.3 \pm 20.3 \mathrm{~A}$ & $132.8 \pm 12.0 \mathrm{~A}$ \\
\hline DIET & & \\
With hairy woodrose & $74.4 \pm 24.7 \mathrm{~A}$ & $127.4 \pm 15.9 \mathrm{~A}$ \\
Without hairy woodrose & $69.2 \pm 21.3 \mathrm{~A}$ & $116.8 \pm 13.0 \mathrm{~B}$ \\
\hline CV & 19.7 & 6.5 \\
\hline
\end{tabular}

Means followed by different letters in the column are different from each other $(\mathrm{P}<0.05)$ by the Tukey's test.

Respiratory rates of 40-60, 60-80, and 80-

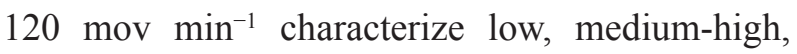
and high stress, respectively, and above 200 mov $\min ^{-1}$, it would characterize a severe stress in sheep (SILANIKOVE, 2000). In the study in question, all sheep presented average RR values representative of medium-high stress.

The heart rate in sheep can vary from 70 to 80 beats $\min ^{-1}$ (REECE, 2007) and variations may occur according to the genetic group. Animals of the genetic group Morada Nova presented a higher $(\mathrm{P}<0.05)$ heart rate when compared to animals of the other two genetic groups, which did not differ from each other. The values of HR were higher in the afternoon period and in animals fed diet with hairy woodrose hay.

The higher temperature in the afternoon leads to the peripheral vasodilation as a thermoregulatory measure and due to an increase in the caliber of blood vessels, a higher blood circulation is observed in the body of the animal. Thus, a heat dissipation by conduction from the central nucleus to the ends of the animal and environment becomes more efficient. Higher HR values may be a reflection of 
vasodilatation, increased blood flow, and a higher ease of blood circulation in the vessels, which occur in animals with a greater need and capacity for heat dissipation, as occurred in Morada Nova sheep in the afternoon period due to an increase in the temperature.

The inclusion of hairy woodrose hay may have caused a higher heat generation due to the digestive metabolism for degradation of the fiber present in this forage. This may have generated a higher caloric increment for the digestion of the hairy woodrose fiber in comparison to the fibrous content of the tifton hay, leading to an increased HR in animals fed hairy woodrose hay.
An effect of the period was observed for all the studied physiological variables, with the highest averages in the afternoon (Table 4). This is due to an increase in the ambient temperature in the afternoon, which causes a decrease in the thermal gradient between the animal and medium, promoting less efficiency in the heat dissipation by the sensible form when compared to latent mechanisms due to the existing radiation load. Thus, the animal begins to lose heat mainly through the latent form by increasing the respiratory rate. Due to a higher heat retention in the evening period, ST, RT, and HR increased, but the animals were able to maintain their homeothermia since the values remained within normal for the species, without hyperthermia.

Table 4. Means of rectal (RT) and surface temperature $(\mathrm{ST})\left({ }^{\circ} \mathrm{C}\right)$ of sheep of the genetic groups Somalis, Dorper $\mathrm{x}$ Somalis, and Morada Nova in the morning and afternoon periods.

\begin{tabular}{lccc}
\hline \multirow{2}{*}{ GENETIC GROUP } & \multicolumn{2}{c}{ RT } & Afternoon \\
\cline { 2 - 4 } & Morning & & $39.61 \mathrm{Aa}$ \\
\hline Somalis & $38.96 \mathrm{Ab}$ & & $39.70 \mathrm{Aa}$ \\
Dorper x Somalis & $38.85 \mathrm{Ab}$ & & $39.29 \mathrm{Ba}$ \\
Morada Nova & $38.34 \mathrm{Bb}$ & 0.45 & \\
\hline CV & & ST & Afternoon \\
\hline & Morning & & $38.18 \mathrm{Aa}$ \\
\hline Somalis & $34.88 \mathrm{Cb}$ & & $38.13 \mathrm{Aa}$ \\
Dorper x Somalis & $36.01 \mathrm{Ab}$ & & $38.03 \mathrm{Aa}$ \\
Morada Nova & $35.55 \mathrm{Bb}$ & 1.07 & \\
\hline CV & & & \\
\hline
\end{tabular}

Means followed by different uppercase letters in the column and lowercase letters in the row are different from each other $(\mathrm{P}<0.05)$ by Tukey's test.

An interaction was observed between periods and genetic groups for the rectal and superficial temperature of sheep. The highest temperatures were obtained in the afternoon period. The Morada Nova breed presented the lowest averages of RT in both periods, thus showing its greater adaptability to the semi-arid region when compared to the other two genetic groups and their greater ability to maintain the temperature within normal levels even in environments that may provide thermal discomfort since animals that present less variation in RT and RR when exposed to thermal stress are considered more heat tolerant.

The RT of animals were within the normal range for the species. According to Reece (2007), it should be $39.1^{\circ} \mathrm{C}$ and according to Cunningham (2004), this variable in sheep can vary from 38.5 to $39.9^{\circ} \mathrm{C}$. 
An effect of the period was observed for surface temperature, with animals presenting higher average values in the afternoon $(\mathrm{P}<0.05)$ due to a higher retention of body heat in this period. A difference $(\mathrm{P}<0.05)$ was observed for surface temperature between genetic groups in the morning period, with the Somalis breed presenting the lowest average followed by Morada Nova and Dorper x Somalis.

The Dorper $\mathrm{x}$ Somalis animals showed a higher ST in the morning period among the three genetic groups. In the afternoon, no significant difference was observed between genetic groups. The animals from the crossbreeding between specialized breeds, such as Dorper and Somalis, present a high tolerance to heat, but still smaller than the tolerance presented by native breeds, such as Morada Nova.

The Morada Nova sheep present a higher heat retention capacity from the radiant heat load (RHL) due to their brown pelage, which is darker in relation to animals of the other genetic groups, which present white fur on most of the body. According to Takahashi et al. (2009), RHL is defined as the total amount of thermal energy exchanged by the animal through radiation with the environment.

The higher absorptivity and lower reflectivity of radiation are responsible for raising the surface temperature in these animals. In this study, this thermal energy was derived from the retransmission of radiant heat by diffuse solar radiation through the facilities and neighboring objects and surfaces to the animals since they were under an intensive production system.

An interaction was observed between the genetic groups and diets on the surface temperature of animals (Table 5).

Table 5. Means of the surface (ST) and rectal temperature (RT) $\left({ }^{\circ} \mathrm{C}\right)$ of sheep of the genetic groups Somalis, Dorper $\mathrm{x}$ Somalis, and Morada Nova as a function of diet with and without hairy woodrose.

\begin{tabular}{|c|c|c|}
\hline \multirow{2}{*}{ GENETIC GROUP } & \multicolumn{2}{|c|}{ RT } \\
\hline & Diet with hairy woodrose & Diet without hairy woodrose \\
\hline Somalis & $39.21 \mathrm{Aa}$ & $39.20 \mathrm{Aa}$ \\
\hline Dorper $\mathrm{x}$ Somalis & $39.20 \mathrm{Aa}$ & 39.19Aa \\
\hline Morada Nova & $38.97 \mathrm{Ba}$ & $38.96 \mathrm{Ba}$ \\
\hline \multirow[t]{3}{*}{$\mathrm{CV}$} & \multicolumn{2}{|c|}{0.45} \\
\hline & \multicolumn{2}{|c|}{ ST } \\
\hline & Diet with hairy woodrose & Diet without hairy woodrose \\
\hline Somalis & $36.79 \mathrm{Aa}$ & $36.26 \mathrm{Bb}$ \\
\hline Dorper $\mathrm{x}$ Somalis & 36.97Aa & $37.17 \mathrm{Aa}$ \\
\hline Morada Nova & $36.97 \mathrm{Aa}$ & $36.61 \mathrm{Ab}$ \\
\hline $\mathrm{CV}$ & \multicolumn{2}{|c|}{1.07} \\
\hline
\end{tabular}

Means followed by different uppercase letters in the column and lowercase letters in the row are different from each other $(\mathrm{P}<0.05)$ by Tukey's test.

In both diets, Morada Nova sheep showed a lower $(\mathrm{P}<0.05)$ rectal temperature when compared to the other genetic groups, which did not differ from each other. The inclusion of hairy woodrose hay did not increase RT values for any of the studied genetic groups.
The surface temperature of the group of animals that received the hairy woodrose hay did not differ from each other. In the group of sheep that received only the tifton hay as roughage, the Somalis breed had the lowest average temperature found by the thermography. This fact can be explained by the 
smaller size of Somalis sheep, which present a higher relative body surface, which is favorable for heat dissipation when compared to larger animals, such as Dorper x Somalis. Moreover, Somalis sheep have a white pelage on most of the body, which provides a higher reflectivity and less heat absorption by the skin when compared to animals with darker pelage (DANTAS et al., 2015), as in sheep of the breed Morada Nova.

The surface temperatures detected using infrared thermography are able to show different responses to the environment depending on the genetic group and are highly correlated with phenotypic traits that affect heat tolerance (PAIM et al., 2013).

Within the same breed group, the animals that received roughage containing hairy woodrose hay showed higher averages for surface temperature in the genetic groups Somalis and Morada Nova. As discussed previously for HR, the increased ST for the animal group fed hairy woodrose hay may be related to the digestive metabolism of the fiber present in this native forage, which would have generated, after animal feeding (at 7 and $14 \mathrm{~h}$, a few hours before ST measurement), a higher caloric increment and heat generation, a behavior that had an impact on ST increase.

However, the increased ST and RR did not interfere with the thermoregulatory capacity of these animals considering the analysis of the physiological responses previously evaluated (RR and RT), which are the two most important variables in the evaluation of tolerance to heat, with no changes due to the inclusion of hairy woodrose hay in the diet.

\section{Conclusions}

The sheep of the three studied genetic groups were adapted and tolerant to the climate conditions of the Brazilian semi-arid region.

The sheep of the Morada Nova genetic group showed a greater adaptability in relation to Somalis and Dorper x Somalis sheep.
A $30 \%$ substitution of tifton hay by hairy woodrose hay did not negatively affect the thermoregulatory capacity of sheep.

\section{References}

ASSOCIAÇÃO BRASILEIRA DE CRIADORES DE OVINOS - ARCO. Padrões raciais. Bagé, RS: ARCO, 2018. Disponível em: <http://www.arcoovinos.com.br/ index.php/mn-srgo/mn-padroesraciais $>$. Acesso em: 19 jun. 2018.

ARRUDA, A. M. V.; ALBUQUERQUE NETO, M. C.; LINHARES, P. C. F.; COSTA, M. R. G.; PEREIRA, E. $\mathrm{S}$. Digestibilidade in vitro da jitirana com inóculo cecal de avestruzes. Revista Brasileira de Saúde e Produção Animal, Salvador, v. 11, n. 2, p. 474-483, 2010.

BAÊTA, F. C.; SOUZA, C. F. Ambiência em edificações rurais: conforto animal. 2. ed. Viçosa, MG: EDUFV, 2010. 269 p

BARBOSA NETO, A. C.; OLIVEIRA, S. M. P.; FACÓ, O.; LÔBO, R. N. B. Efeitos genéticos aditivos e nãoaditivos em características de crescimento, reprodutivas e habilidade materna em ovinos das raças Santa Inês, Somalis Brasileira, Dorper e Poll Dorset. Revista Brasileira de Zootecnia, Viçosa, MG, v. 39, n. 9, p. 19431951, 2010.

BUFFINGTON, D. E.; COLLAZO-AROCHO, A.; CANTON, G. H.; PITT, D.; THATCHER, W. W.; COLLIER, R. J. Black-Globe-Humidity Index (BGHI) as comfort equations for dairy cows. Transactions of the $A S A E$, St. Joseph, v. 24, n. 3, p. 711-14, 1981.

CRUZ JÚNIOR, C. A.; LUCCI, C. M.; PERIPOLLIA, V.; TANUREA, C. B.; RIBEIRO, L. M. C. S.; BARBOSA, T. M.; RAMOS, A. F.; LOUVANDINI, H.; McMANUS, C. Laser and thermographic infrared temperatures associated with heat tolerance in adult rams. Small Ruminant Research, Amsterdam, v. 132, p. 86-91, 2015.

CUNNINGHAM, J. G. Tratado de fisiologia veterinária. 3. ed. Rio de Janeiro: Guanabara Koogan, 2004. 596 p.

DANTAS, N. L. B.; SOUZA, B. B.; CÉZAR, M. F.; OLIVEIRA, G. J. C.; ARAÚJO, R. P.; NOBRE, I. S.; MEDEIROS, S. F.; ROBERTO, J. V. B. Estudos da coloração do pelame em relação às respostas produtivas de ovinos mestiços sob estresse calórico. Revista Brasileira de Saúde e Produção Animal, Salvador, v. 16, n. 2, p. 397-407, 2015.

FACÓ, O.; PAIVA, S. R.; ALVES, L. R. N.; LÔBO, R. N. B.; VILLELA, L. C. V. Raça Morada Nova: origem, características e perspectivas. Sobral: EMBRAPA 
Caprinos, 2008. 43 p. (Documentos / EMBRAPA Caprinos, 75). Disponível em: <https:/www.infoteca. cnptia.embrapa.br/bitstream/doc/533728/1/doc75.pdf $>$. Acesso em: 15 set. 2017.

HEWITT, P. G. Física conceitual. 12. ed. Porto Alegre: Bookman, 2015. 816 p.

INSTITUTO BRASILEIRO DE GEOGRAFIA E ESTATÍSTICA - IBGE. Pesquisa Pecuária Municipal (PPM) 2015. Rio de Janeiro: EDITORA, 2016. v. 43, $100 \mathrm{p}$.

INSTITUTO NACIONAL DE METEOROLOGIA INMET. Dados meteorológicos. Brasília, DF: Ministério da Agricultura, Pecuária e Abastecimento, 2018. Disponível em: <http://www.inmet.gov.br/ portal/index. php? $\mathrm{r}=$ estacoes/estacoesautomaticas $>$. Acesso em: 18 set. 2018.

LEÃO, E. S.; TORREÃO, J. N. C.; ARAÚJO, M. J.; BEZERRA, L. R.; MARQUES, C. A. T.; FERREIRA, R. R.; NASCIMENTO, R. R.; LEANDRO, B. S.; EDVAN, R. L. Analysis of the potentiality haying of native forage species in semiarid region. Semina: Ciências Agrárias, Londrina, v. 38, n. 5, p. 3319-3330, 2017.

LEITÃO, M. M. V. B. R.; OliVEIRA, G. M.; ALMEIDA, A. C.; SOUSA, P. H. F. Conforto e estresse térmico em ovinos no Norte da Bahia. Revista Brasileira de Engenharia Agrícola e Ambiental, Campina Grande, v. 17, n. 12, p. 1355-1360, 2013.

NATIONAL RESEARCH COUNCIL - NRC. Nutrient requirements of small ruminants: sheep, goats, cervids, and new world camelids. Washington: National Academy Press, 2007. 384 p.

OLIVEIRA, F. A.; TURCO, S. H. N.; BORGES, I.; CLEMENTE, C. A. A.; NASCIMENTO, T. V. C.; LOIOLA FILHO, J. B. Parâmetros fisiológicos de ovinos Santa Inês submetidos a sombreamento com tela de polipropileno. Revista Brasileira de Engenharia Agrícola e Ambiental, Campina Grande, v. 17, n. 9, p. 1014-1019, 2013.
PAIM, T. P.; BORGES, B. O.; LIMA, P. M. T.; GOMES, E. F.; DALLAGO, B. S.; FADEL, R.; MENEZES, A. M.; LOUVANDINI, H.; CANOZZI, M. E.; BARCELLOS, J. O.; McMANUS, C. Thermographic evaluation of climatic conditions on lambs from different genetic groups. International Journal of Biometeorology, New York, v. 57, n. 1, p. 59-66, 2013.

REECE, W. O. Dukes fisiologia dos animais domésticos. 12. ed. Rio de Janeiro: Guanabara Koogan, 2007. 926 p.

RIBEIRO, E. L. A.; GARCÍA, E. G. Indigenous sheep breeds in Brazil: potential role for contributing to the sustainability of production systems. Tropical Animal Health and Production, Edinburgh, v. 48, n. 7, p. 13051313, 2016.

SEIXAS, L.; MELO, C. B.; TANURE, C. B.; PERIPOLLI, V.; McMANUS, C. Heat tolerance in Brazilian hair sheep. Asian-Australasian Journal of Animal Sciences, Seoul, v. 30, n. 4, p. 593-601, 2017.

SILANIKOVE, N. Effects of heat stress on the welfare of extensively managed domestic ruminants. Livestock Production Science, Bet Dagan, v. 67, n. 1-2, p. 1-18, 2000.

SILVA, D. C.; SEAL, D. C. M.; SOUZA, F. J. C.; CARVAlHO, A. B.; MARQUES, A. V. M. S. Consumo e digestibilidade de dietas contendo feno de jitirana para ovinos em terminação. Revista Verde de Agroecologia e Desenvolvimento Sustentável, Pombal, v. 12, n. 1, p. 150$155,2017$.

SOUZA, B. B. Índice de conforto térmico para ovinos e caprinos: índice de temperatura do globo negro e umidade registrado em pesquisas no Brasil. Piracicaba: Agripoint, 2010. Disponível em: < http://www.milkpoint. com.br>. Acesso em: 5 out. 2016.

TAKAHASHI, L. S.; BILLER, J. D.; TAKAHASHI, K. M. Bioclimatologia zootécnica. Jaboticabal: Funep, 2009. 91 p.

UNIVERSIDADE FEDERAL DE VIÇOSA - UFV. Manual de utilização do programa SAEG (Sistema para análises estatísticas e genéticas). Viçosa: Fundação Arthur Bernardes, 1993. 